\title{
The effect of different biostimulators on morphological and biochemical parameters of micropropagated Hosta 'Gold Drop'
}

\author{
Ördögh, M., Beregi, Zs. \& Tillyné Mándy, A. \\ Department of Floriculture and Dendrology, Faculty of Horticultural Science, Szent István University, \\ H-1118 Budapest, 35-43. Villányi str., Hungary, \\ Author for correspondence: ordogh.mate@kertk.szie.hu
}

\begin{abstract}
Summary: During in vitro multiplication of Hosta 'Gold Drop', $20 \mathrm{~g} \mathrm{l}^{-1}$ sucrose, $5.5 \mathrm{~g} \mathrm{l}^{-1}$ agar and 4 concentrations $\left(0.1-0.8 \mathrm{ml} \mathrm{l^{-1 }}\right)$ of Ferbanat L, Kelpak, Pentakeep-V were added to half-strength Murashige and Skoog (MS) basal medium. As compared to the control and other biostimulators, plants with lower peroxidase activity, larger fresh weight, more, longer shoots and roots, larger leaves were developed on medium containing Kelpak. The best concentration was $0.4 \mathrm{ml} \mathrm{l}^{-1}$ for in vitro rooting, shoot formation, plant weight and ex vitro chlorophyll, carotenoid level, peroxidase activity. Pentakeep was the less efficient biostimulator, increasing of its concentration mostly decreased root and shoot values (furthermore, abnormal callus formation was observed, as non-wanted effect), chlorophyll content and sizes (length, width) of leaves, not only during in vitro propagation but also (as after-effect) acclimatization because of the high mortality and weakly developed survivor plants.
\end{abstract}

Ördögh, M., Beregi, Zs., Tillyné Mándy, A. (2019): The effect of different biostimulators on morphological and biochemical parameters of micropropagated Hosta 'Gold Drop'. International Journal of Horticultural Science 25(1-2): 22-29. https://doi.org/10.31421/IJHS/25/1-2./2357

Key words: biostimulator, callus, Hosta, multiplication, acclimatization

\section{Introduction}

In order to eliminate harmful environmental effects, considerable limitations have been placed on several compounds applied in horticultural production, which consist synthetic growth regulators (e.g. auxins) and plant protection chemicals (Ludwig-Muller, 2000). Therefore, environmentally friendly, substitutive formulations such as biostimulators (which can be used only under definite, accurate registration requirements) are often come into focus (Dąbrowski, 2008) and certain preparations, such as Kelpak, Pentakeep-V might be an alternative to chemicals banned by EU (Dobrzański et al., 2008). Biostimulators contain different growth regulators or other hormonal components. These natural, organic preparations often decrease stresses, increase physiological activity, accelerate root development and regularly applied in horticulture but rarely in plant propagation (Szabó et al., 2011).

Positive results during ornamental floriculture application of relevant biostimulators (Pentakeep-V, Kelpak, Ferbanat L) have already reported. The chlorophyll-precursor (Vágújfalvi 2007; Kosáry, 2008) 5-amino-levulinic-acid (ALA) containing Pentakeep-V resulted more lateral shoots of Tillandsia usneoides when optimal concentration $\left(0.5 \mathrm{ml} \mathrm{l}^{-1}\right)$ was used (Tilly-Mándy et al., 2010a). In the case of growing Petunia cv. Veranda 'Rose Vein' seedlings, compact plants with smaller leaf-area, earlier flowering time and more flowers were produced in the presence of $0.3 \mathrm{ml} \mathrm{l}^{-1}$ Pentakeep-V (Duchaj, 2011). The same (and higher: $0.5 \mathrm{ml} \mathrm{l}^{-1}$ ) dose was optimal for Saintpaulia ionantha (Tilly-Mándy et al., 2010b), because treated plants produced flowers two weeks earlier than the control and developed larger leaf-rozettes with higher chlorophyll concentration. Similarly, Begonia $x$ tuberhybrida
'Nonstop' plants' growing time was shortened, and the chlorophyll contents of their leaves was higher especially when $0.5 \mathrm{ml} \mathrm{l}^{-1}$ Pentakeep-solution was sprayed (Kisvarga et al., 2015). Awad (2008) also experienced that the use of 0.04 or $0.08 \%$ Pentakeep-V resulted more chlorophyll and faster growing of Phoenix dactylifera 'Kalas': treated specimens got the value for marketable condition 4-5 months sooner than by the control plants. If Pelargonium zonale 'Serena' cuttings were soaked or soaked + sprayed with $0.5 \%$ Pentakeep-V, significantly longer, more and heavier roots were formed, but no significant differences were obtained between the way of biostimulator application (Köbli et al., 2012). Compared to the untreated groups, treatment significantly increased the bulb yield (bulb number and size) of Tulipa varieties 'Leen van der Mark' and 'Ballerina' (Yoshida et al., 2006). 0.03 or $0,05 \%$ Pentakeep-V gave the best results (heavier, more corms or bulbs) of other bulbous ornamental cut flowers like Allium christophii, Tulipa 'Lucky Strike', Lilium 'Star Gazer' and Gladiolus 'White Frienship' (Krzyminska, 2007). With the use of Pentakeep-V during cut flower production of Lilium cultivars (Abay, 2014), higher chlorophyll content, better vegetative developments, enhanced $\mathrm{CO}_{2}$ assimilation were detected.

Another seaweed product Kelpak (in dilution 0.2\%) positively influenced the growth of Sorbus aucuparia seedlings, their plant height, root and caliper characteristics were significantly higher (Magyar et al., 2008). The same treatment increased the number and weight of shoots of Prunus Marianna 'GF 8-1' and $P$. mahaleb 'Bogdány' stockplants. In case of 'GF-8-1' cultivar, improvement of leaf chlorophyll 
content was also detected (Szabó \& Hrotkó, 2009). Furthermore, application of this biostimulator on 'GF-8-1' stockplants resulted the highest ratio of rooting and enhanced the fresh weight of cutting during rooting in comparison with non-treated (control) cuttings (Szabó et al, 2011), and higher rooting rate of Prunus mahaleb 'Magyar' (a difficult-to-root cultivar) cuttings was obtained (Szabó, 2015).

The use of Ferbanat L (also known as Bistep) and Kelpak equally increased root weight, but further Ferbanat treatment (in 0.2 and $0.4 \%$ concentration) resulted longer stems and significantly larger flower buds of Lilium oriental hybrid cv. 'Rialto' (Tilly-Mándy et al., 2012; Takács et al., 2015). During growing of Petunia $x$ grandiflora 'Musica Blue' seedlings, $0.1 \%$ Ferbanat $\mathrm{L}$ improved shoot development, and further growth was achieved in the presence of higher $(0.2$ or $0.3 \%)$ doses (Kisvarga et al., 2014). For container growth Forsythia $x$ intermedia 'Beatrix Farrand' plants, $0.5 \%$ solution was the best because of the larger root and shoot weight, longer shoots with more, larger, thicker leaves (Kovács et al., 2017).

In order to successful in vitro propagation of different plants, wide variety of natural, phytogenic substances can be used (Jámborné \& Dobránszki, 2005). Although chemically defined accessories are generally used to the media, sometimes, organic supplements are optional and useful (Molnár et al., 2011). Few cases, Kelpak, Ferbanat L, Pentakeep-V biostimulators were used as ingredients of in vitro media.

Kelpak is a brown alga (Ecklonia maxima) extract, prepared by a cell burst process and its active components were suggested to be auxins and cytokinins (Featonby-Smith and Van Staden, 1984). During in vitro propagation of potato cv. 'BP1' (Kowalski et al., 1999), results shown that the use of this easy-to-apply, cheap product rejuvenated all plantlets, but higher Kelpak concentration $(0.5$ and $1 \%)$ decreased shoot length, fresh weight and reduce root development; thus, optimally lower $(0.25 \%)$ dose of Kelpak eventuated larger plants with well-developed rootage. More roots, higher chlorophyll content, heavier in vitro Melissa officinalis plants were found in the presence of this seaweed product (1\% was optimal dose), and for best proliferation of potatoes, higher $(1,5 \%)$ concentration was recommended (Tantos, 2002). Sorbus borbasii 'Herkulesfürdö' plants required lower Kelpak levels $\left(0.1\right.$ or $0.2 \mathrm{ml} \mathrm{l}^{-1}$ instead of $\left.0.4,0.8 \mathrm{ml} \mathrm{l}^{-1}\right)$ in favour of sufficient shoot formation and higher chlorophyll, but no roots developed with the use of any quantity of this biostimulator (Vidák, 2014).

The application of $0.1 \mathrm{ml} \mathrm{l}^{-1}$ Ferbanat $\mathrm{L}$ decreased peroxidase enzyme activity, and higher dose $\left(0.5 \mathrm{ml} \mathrm{l}^{-1}\right)$ increased root length, number of new leaves and chlorophyll contents of in vitro Myrmecophyla tibicinis and Peristeria elata orchid plants culturing on modified MKC (Knudson, 1946) basal medium. The highest level $\left(1 \mathrm{ml} \mathrm{l}^{-1}\right)$ of this agent resulted slower, weaker growing, lower chlorophyll and higher peroxidase values (Thuróczy, 2012). In contrast, the most concentrated Ferbanat $\mathrm{L}$ solution $\left(0.8 \mathrm{ml} \mathrm{l}^{-1}\right)$ resulted the highest chlorophyll, carotenoid content and the lowest peroxidase enzyme activity of in vitro Sorbus borbasii 'Herkulesfürdö' plants. For this Hungarian sorb cultivar, Pentakeep-V has similar positive effect on the same physiological features (and additionally, on the number of shoots, size of leaves) especially with the application of the highest $\left(0.8 \mathrm{ml} \mathrm{l}^{-1}\right)$ dose (Vidák, 2014). The same (and halfstrength, $0.4 \mathrm{ml} \mathrm{l}^{-1}$ ) concentration of this product resulted the highest number of in vitro developed shoots and the longest leaves (with the highest chlorophyll content) of Philodendron erubescens, however, the higher concentration of Pentakeep-V decreased the length of roots. Additionally, acclimatized Philodendron erubescens plants grown higher and developed longer leaves when previously cultured them on medium contained Pentakeep-V comparing the control (Asztalos, 2014).

Plantain lilies (members of the genus Hosta, belonged to the Asparagaceae family) are popular, shade tolerant EastAsian (mainly Japanese) ornamental perennial plants with robust rhizome, variable leaves and attractive, white or violetblue, bell-shaped, summer flowers with low pollen, total sugar mass production (Bozek et al., 2015). Hosta propagation by seeds or division are conventional but relatively unproductive methods with heterogeneous, slow growing seedlings and/or low multiplication ratio (Hamrick, 2003; Rice, 2006). If largescale production of pathogen-free, uniform, high-quality plants is required, micropropagation is economical and efficient (Jámborné and Dobránszki, 2005). Several Hosta cultivars were efficiently in vitro cultured on Murashige and Skoog (MS, 1962) basic medium, and type or concentration of plant hormones was often depended on the cultivars. As example, 6 $\mathrm{mg} \mathrm{l}^{-1}$ benzyle-aminopurin (BAP) was optimal for $H$. 'Devon Green', $H$. 'Blue Cadet', $H$. 'Samurai', while $H$. 'Gold Haze', $H$. 'Gold Drop' needed lower dilution, only $3 \mathrm{mg} \mathrm{l}^{-1}$. As sourcing carbohydrates, 20-35 $\mathrm{g} \mathrm{l}^{-1}$ sucrose is recommended, accordingly to the cultivars (Szafián, 2010). Sometimes, agarfree, liquid media resulted more in vitro shoots, roots and greater dry weight (Adelberg et al., 2000; Adelberg, 2005).

For our study, we chose an easy-to-care, trouble free cultivar as test plant, Hosta 'Gold Drop'. Previously, a similar (but white-patterned) cv. Hosta 'Dew Drop' was successfully micropropagated by in vitro application of Pentakeep-V, Ferbanat L and Kelpak (instead of different auxins and/or cytokinins). These biostimulators effectively improved the number and fresh weight of in vitro grown shoots and (as aftereffect) acclimatizated plants usually developed larger leaves with higher chlorophyll and carotenoid contents especially when Ferbanat L or Kelpak was previously applied during in vitro propagation (Gere, 2017). Due to these positive results, we wanted to know whether Hosta 'Gold Drop' gives similar or different reactions if we use the same type and concentration of biostimulators.

\section{Materials and methods}

\section{Origin of plant material}

The experiments were carried out with the use of rootless, 2.5-3 cm sized, 3 leaved shoots as explants originated from in vitro stock of Hosta 'Gold Drop', a dwarf-sized cultivar with small, pale, yellowish-green leaves and violet flowers (Schmid, 1991; Liu and Zhao, 2012). The in vitro and acclimatization studies were done in the laboratory and greenhouse of the Department of Floriculture and Dendrology, Szent István University.

\section{Culture establishment}

For in vitro culturing, rootless shoots with 3-4 leaves (as explants) were planted on Murashige and Skoog (MS, 1962) basal medium with half-strength macroelements as control and four different concentrations $\left(0.1,0.2,0.4,0.8 \mathrm{ml} \mathrm{l}^{-1}\right)$ of three biostimulators, Ferbanat L (originally made by the Turkish Ekosistem company, in Hungary, it was allowed as „Bistep 
plant conditioner"), Kelpak (Kelp Products Ltd., South Africa) and Pentakeep-V (Cosmo Seiwa Agriculture Ltd., Japan). The control did not contain biostimulator at all. Every medium contained $20 \mathrm{~g} \mathrm{l}^{-1}$ sucrose (Reanal Finomvegyszergyár Zrt., Hungary) and $5.5 \mathrm{~g} \mathrm{l}^{-1}$ agar (Sigma-Aldrich, Merck, USA). The $\mathrm{pH}$ was adjusted to 5.6 with $\mathrm{KOH}$ and autoclaving was done for 35 minutes on overpressure $\left(10^{5} \mathrm{~Pa}\right)$. In vitro cultures were maintained at $22 \pm{ }^{\circ} \mathrm{C}$ under $16 / 8$ photoperiod with a photosynthetic photon flux density of $40 \mu \mathrm{mol} \mathrm{m} \mathrm{m}^{-1} \mathrm{~s}^{-1} \cdot 14$ weeks later, in vitro morphological data (shoot and root number and length, leaf length and width, fresh plant weight) were recorded.

For determining the after effect of examined biostimulators in vitro grown plants from every treatment were transplanted into a soil mix of $50 \%$ perlite $+50 \%$ peat as acclimatization in greenhouse conditions $\left(70 \%\right.$ relative air humidity, $20-25{ }^{\circ} \mathrm{C}$, without artificial lighting and fertilization). Worthy of note: the use of in vitro rooting medium (containing different types or concentrations of auxins) was not necessary before acclimatization, because we observed spontaneous root development during in vitro Hosta 'Gold Drop' culturing on all medium with or without biostimulators. Twenty weeks after the start of acclimatization, ex vitro shoot and leaf parameters namely number and length of shoots, length and width of leaves were measured (plant weight, roots were not examined in order to avoid plant's injuries). Additionally, rate of abnormally developed in vitro plants (with callus) and survival of ex vitro (acclimatized) specimens were determined. Important to note that only the after-effects of in vitro applied biostimulators were studied in the stage of acclimatization, that is why uniform soil mix was used for every plant specimen. Each experiment was repeated twice and 30 plants per treatment was examined.

\section{Measurement of biochemical parameters}

For determination of chlorophyll $a+b$ (thereinafter: chlorophyll) and carotenoid content, $100 \mathrm{mg}$ leaf sample was used from both in vitro and acclimatized plants, three fold per treatment. Leaves were homogenized by a dash of quartz sand and $10 \mathrm{ml}$ acetone (80\%). After 24 hour cooling on $+4{ }^{\circ} \mathrm{C}$ absorbance of solution was measured by GeneSys VIS-10 (Thermo Fisher Scientific Inc., USA) spectrophotometer at 644, 663 and $480 \mathrm{~nm}$ wavelength. Chlorophyll and carotenoid contents $\left(\mu \mathrm{g} \mathrm{g}^{-1}\right)$ were calculated by formula $(20.2 \times \mathrm{A} 644+$ $8.02 \times \mathrm{A} 663) \times \mathrm{V} / \mathrm{w}$ and $\left(5.01 \times \mathrm{A}_{480}\right) / \mathrm{w}$; where $\mathrm{V}=$ volume of tissue extract $(10 \mathrm{ml}), \mathrm{w}=$ fresh weight of tissue $(0.1 \mathrm{~g}), \mathrm{A}=$ absorbance (Arnon, 1949).

In the case of assaying peroxidase (POD) activity, $3 \times 150$ $\mathrm{mg}$ leaf (from in vitro and ex vitro plants) per treatment were homogenized in a refrigerated mortar with the use of $1.5 \mathrm{ml}$ $\mathrm{KH}_{2} \mathrm{PO}_{4}(\mathrm{pH}=6.5,0.05 \mathrm{M})$. After centrifuging $\left(4{ }^{\circ} \mathrm{C}, 20\right.$ minutes, $13500 \mathrm{rpm}$ ), separated extracts (without solid particles) were used for spectrophotometric investigations (adjusted wavelength: $460 \mathrm{~nm}$ ). For reaction, plant-extracts (3 $\times 0.01 \mathrm{ml} /$ treatment) were mixed with $1.7 \mathrm{ml} \mathrm{C}_{2} \mathrm{H}_{3} \mathrm{NaO}_{2}$ ( $\mathrm{pH}=4.5,0.1 \mathrm{M}), 0.03 \mathrm{ml} \mathrm{H}_{2} \mathrm{O}_{2}$ and $0.02 \mathrm{ml}$ ortho-dianisidine (3, 3'-dimethoxybenzidine) as chromogen reagent. Enzyme activity $\left(\mathrm{U} \mathrm{mg} \mathrm{mg}^{-1}\right)$ was calculated with formula $(\Delta \mathrm{A} 1 \times$ attenuation $) / \varepsilon$; where $\Delta \mathrm{A} 1=$ absorbance change $/ 1 \mathrm{~min}, \varepsilon=$ 11.3: extinction coefficient of ortho-dianisidine (Shannon et al, 1966; Blinda et al., 1996).

Three repetitions from every treatment was used for examinations of all biochemical parameters.

\section{Data and statistical analysis}

Data (chlorophyll and carotenoid content, POD activity, length and width of leaves, number and length of shoots and roots, fresh weight of plants) were evaluated by SPSS 23.0 (IBM Corp., USA). An analysis of variance (ANOVA) was conducted to calculate the statistical significance of all data presented. When significant differences between treatments were found, the means were separated by Tukey's and GamesHowell's test at $\mathrm{p} \leq 0.05$.

\section{Results and discussion}

\section{Number and length or roots}

In vitro root number and length were the highest on medium supplemented with $0.1 \mathrm{ml} \mathrm{l}^{-1}$ Ferbanat (32.13 and $83.93 \mathrm{~mm}$ ), or $0.4 \mathrm{ml} \mathrm{l}^{-1}$ Kelpak (34.23 and $78.2 \mathrm{~mm}$, Figure 1 A). More concentration of Pentakeep eventuated less and shorter roots, significantly the lowest values were observed when $0.8 \mathrm{ml} \mathrm{l}^{-1}$ Pentakeep was used (Figure 1 B, Table 1). Direct proportion was experienced between root number and length. In another trial (Hosta 'Dew Drop' micropropagation - Gere, 2017), the longest and the highest number of roots were achieved on medium supplemented with 0.1, $0.2 \mathrm{ml} \mathrm{l}^{-1}$ Pentakeep (26.76 and 24.55 root) and $0.2,0.4 \mathrm{ml} \mathrm{l}^{-1}$ Ferbanat ( 88.47 and $81.88 \mathrm{~mm}$ ). Increasing of Pentakeep concentration decreased the number and length of roots, similarly to our research.

Table 1. Root number and length, fresh weight of in vitro grown Hosta 'Gold Drop' plants cultured on Murashige and Skoog (1962) medium with 0.1-0.8 ml $\mathrm{L}^{-1}$ Ferbanat L, Kelpak, Pentakeep-V. Data represented by mean \pm standard deviation (SD). Means with different letters are significantly different according to Tukey's and Games-Howell's comparison test at $\mathrm{p} \leq 0.05$

\begin{tabular}{|c|c|c|c|c|}
\hline & & $\begin{array}{l}\text { Root number } \\
\quad \pm \text { SD }\end{array}$ & $\begin{array}{c}\text { Root length }(\mathbf{m m}) \\
\pm \text { SD }\end{array}$ & $\begin{array}{l}\text { Fresh plant } \\
\text { weight (g) } \\
\quad \pm \text { SD }\end{array}$ \\
\hline \multicolumn{2}{|c|}{ Control } & $31.48 \pm 7.86 \mathrm{efg}$ & $83.25 \pm 34.87 \mathrm{e}$ & $1.5 \pm 0.82 \mathrm{bc}$ \\
\hline \multirow{4}{*}{$\begin{array}{c}\text { Ferbanat L } \\
\left(\mathrm{ml} \mathrm{l}^{-1}\right)\end{array}$} & 0.1 & $32.13 \pm 6.35 \mathrm{fg}$ & $83.93 \pm 29.61 \mathrm{e}$ & $1.48 \pm 0.57 \mathrm{bc}$ \\
\hline & 0.2 & $26.86 \pm 5.44 \mathrm{cde}$ & $82.1 \pm 36.82 \mathrm{e}$ & $1.31 \pm 0.66 \mathrm{bc}$ \\
\hline & 0.4 & $23.8 \pm 3.33 \mathrm{bc}$ & $51.73 \pm 17.06 \mathrm{~b}$ & $1.33 \pm 0.4 \mathrm{bc}$ \\
\hline & 0.8 & $25.46 \pm 6.06 \mathrm{~cd}$ & $59 \pm 31.4 \mathrm{bcd}$ & $1.43 \pm 0.44 \mathrm{bc}$ \\
\hline \multirow{4}{*}{$\begin{array}{l}\text { Kelpak } \\
\left(\mathrm{ml} \mathrm{l}^{-1}\right)\end{array}$} & 0.1 & $28.86 \pm 5.65 \mathrm{def}$ & $62.93 \pm 23.91 \mathrm{bcde}$ & $1.68 \pm 0.61 \mathrm{bc}$ \\
\hline & 0.2 & $33.1 \pm 4.89 \mathrm{fg}$ & $77.1 \pm 23.63 \mathrm{cde}$ & $2.26 \pm 0.65 \mathrm{de}$ \\
\hline & 0.4 & $34.23 \pm 5.41 \mathrm{~g}$ & $78.2 \pm 29.21 \mathrm{de}$ & $2.53 \pm 0.95 \mathrm{e}$ \\
\hline & 0.8 & $26.86 \pm 4.28 \mathrm{cde}$ & $44.46 \pm 10.8 \mathrm{~b}$ & $1.74 \pm 0.71 \mathrm{~cd}$ \\
\hline \multirow{4}{*}{$\begin{array}{c}\text { Pentakeep- } \\
\text { V } \\
\left(\mathrm{ml} \mathrm{l}^{-1}\right)\end{array}$} & 0.1 & $27.17 \pm 4.75 \mathrm{cde}$ & $55.75 \pm 19.44 \mathrm{bc}$ & $1.44 \pm 0.74 \mathrm{bc}$ \\
\hline & 0.2 & $22.75 \pm 5.38 \mathrm{bc}$ & $49.58 \pm 15.4 \mathrm{~b}$ & $1.14 \pm 0.56 \mathrm{ab}$ \\
\hline & 0.4 & $20.37 \pm 6.13 b$ & $41.75 \pm 20.16 b$ & $1.17 \pm 0.48 \mathrm{abc}$ \\
\hline & 0.8 & $5.07 \pm 3.12 \mathrm{a}$ & $7.6 \pm 5.47 \mathrm{a}$ & $0.7 \pm 0.52 \mathrm{a}$ \\
\hline
\end{tabular}

\section{Fresh plant weight}

Kelpak in every concentrations resulted the heaviest in vitro plants, especially in the case of 0.2 and $0.4 \mathrm{ml}^{-1}$, when significantly higher values $(2.26$ and $2.53 \mathrm{~g})$ were obtained. It is worth notify that the latter treatment also effected the most and longest shoots and the lowest leaf, root averages were achieved on medium with Pentakeep. During in vitro propagation of Hosta 'Dew Drop' (Gere, 2017), 0.2 and $0.4 \mathrm{ml}$ $1^{-1}$ Ferbanat was the best for fresh weight (2.62 and $\left.2.93 \mathrm{~g}\right)$, furthermore, the same treatments enhanced shooting, shoot and root length principally. 

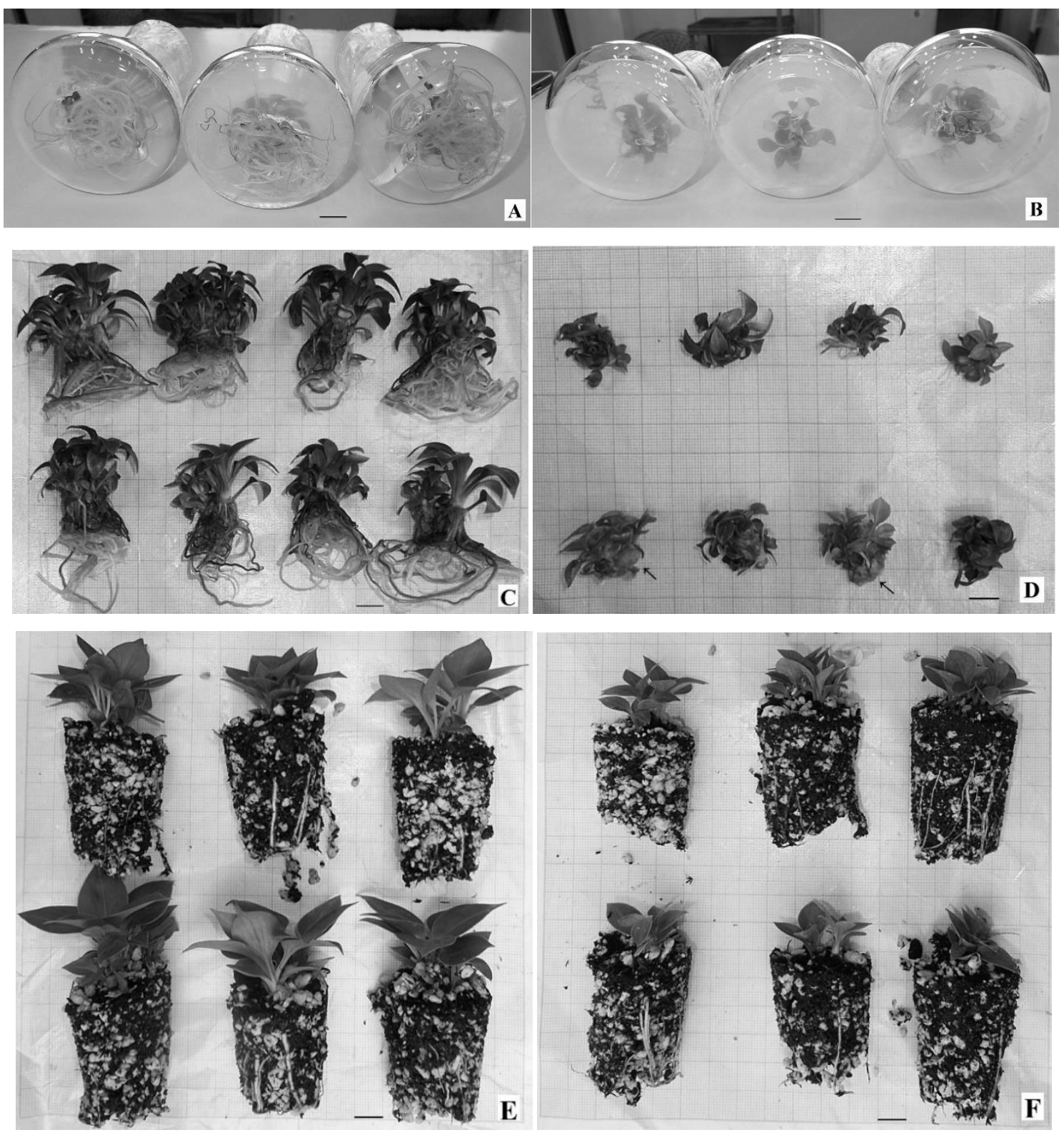

Figure 1. Hosta 'Gold Drop' in vitro and acclimatized (ex vitro) plants: A) Well rooted specimens in $100 \mathrm{ml}$ Erlenmeyer flasks containing $1 / 2$ MS medium with 0.4 $\mathrm{ml} \mathrm{l}^{-1}$ Kelpak. (B) $0.8 \mathrm{ml} \mathrm{l}^{-1}$ Pentakeep-V resulted plants without or only few, short roots. C) In vitro plants cultured on $1 / 2 \mathrm{MS}$ medium supplemented with 0.4 ml $1^{-1}$ Kelpak produced more and longer shoots with larger leaves. D) Poorly developed in vitro plants (callus formation shown by arrows) from $1 / 2$ MS medium containing $0.8 \mathrm{ml} \mathrm{l}^{-1}$ Pentakeep-V. E) Ex vitro plants grown better when Kelpak was used before acclimatization. F) As after-effect, Pentakeep resulted weaker ex vitro plants Scale bars on pictures: $10 \mathrm{~mm}$.

\section{Number and length of shoots}

Almost every concentration of Kelpak resulted more in vitro shoots as compared with the control, and the highest number (5.43) were achieved on medium supplemented with $0.4 \mathrm{ml} \mathrm{l}^{-1}$ Kelpak (Figure $1 \boldsymbol{C}$ ). Similar value was detected in the case of using $0.8 \mathrm{ml} \mathrm{l}^{-1}$ Pentakeep, although this treatment resulted abnormal callus formation (Figure $1 \boldsymbol{D})$ as non-wanted effect in $39.28 \%$ of the in vitro Hosta 'Gold Drop' plants. Anyways, this biostimulator (especially in higher concentration) was the best for shoot multiplication of in vitro Philodendron erubescens (Asztalos, 2014).

Significantly, the longest Hosta 'Gold Drop' in vitro shoots were found when $0.4 \mathrm{ml} \mathrm{l}^{-1}$ Kelpak was added to the medium, and only this biostimulator resulted longer shoots in every concentration comparing to the control. Higher level of Pentakeep decreased length of shoots, so the shortest $(16.46$ $\mathrm{mm}$ ) ones were formed with the presence of $0.8 \mathrm{ml} \mathrm{l}^{-1}$ of this agent. In contrast, Philodendron erubescens produced the longest in vitro shoots with the use of latter biostimulator (Asztalos, 2014), and Kelpak had the worst effect in every dose if Sorbus borbasii 'Herkulesfürdö' was in vitro propagated on media contained this agent (Vidák, 2014).

The highest number of acclimatized (ex vitro) shoots (4.834.94) were found in groups of 0.2-0.8 $\mathrm{ml} \mathrm{l}^{-1}$ Kelpak (Figure 1 $\boldsymbol{E})$. Additionally, higher doses of Pentakeep after-effected fewer (and shorter) shoots of acclimatized plants (Figure 1 F). As compared with the other biostimulators, Kelpak was the best (as after-effect) for elongation: the longest (31.86-39.32 $\mathrm{mm}$ ) shoots were developed in this group (Table 2). In another study (Gere, 2017), more (4.85-5.23) and longer (26.07-26.45 $\mathrm{mm}$ ) shoots of in vitro Hosta 'Dew Drop' were found on medium containing $0.1-0.4 \mathrm{ml} \mathrm{l}^{-1}$ Ferbanat. As after-effect, mainly this biostimulator eventuated the greatest shooting, and higher (0.4-0.8 $\left.\mathrm{ml} \mathrm{l}^{-1}\right)$ level of Ferbanat was the best for shoot length of acclimatized plants. Therefore, biostimulators have cultivar-specific effect. 
Table 2. Shoot and leaf parameters of in vitro and ex vitro Hosta 'Gold Drop' plants. Data represented by mean \pm standard deviation (SD). Means with different letter are significantly different according to Tukey's and Games-Howell's comparison test at $\mathrm{p} \leq 0.05$

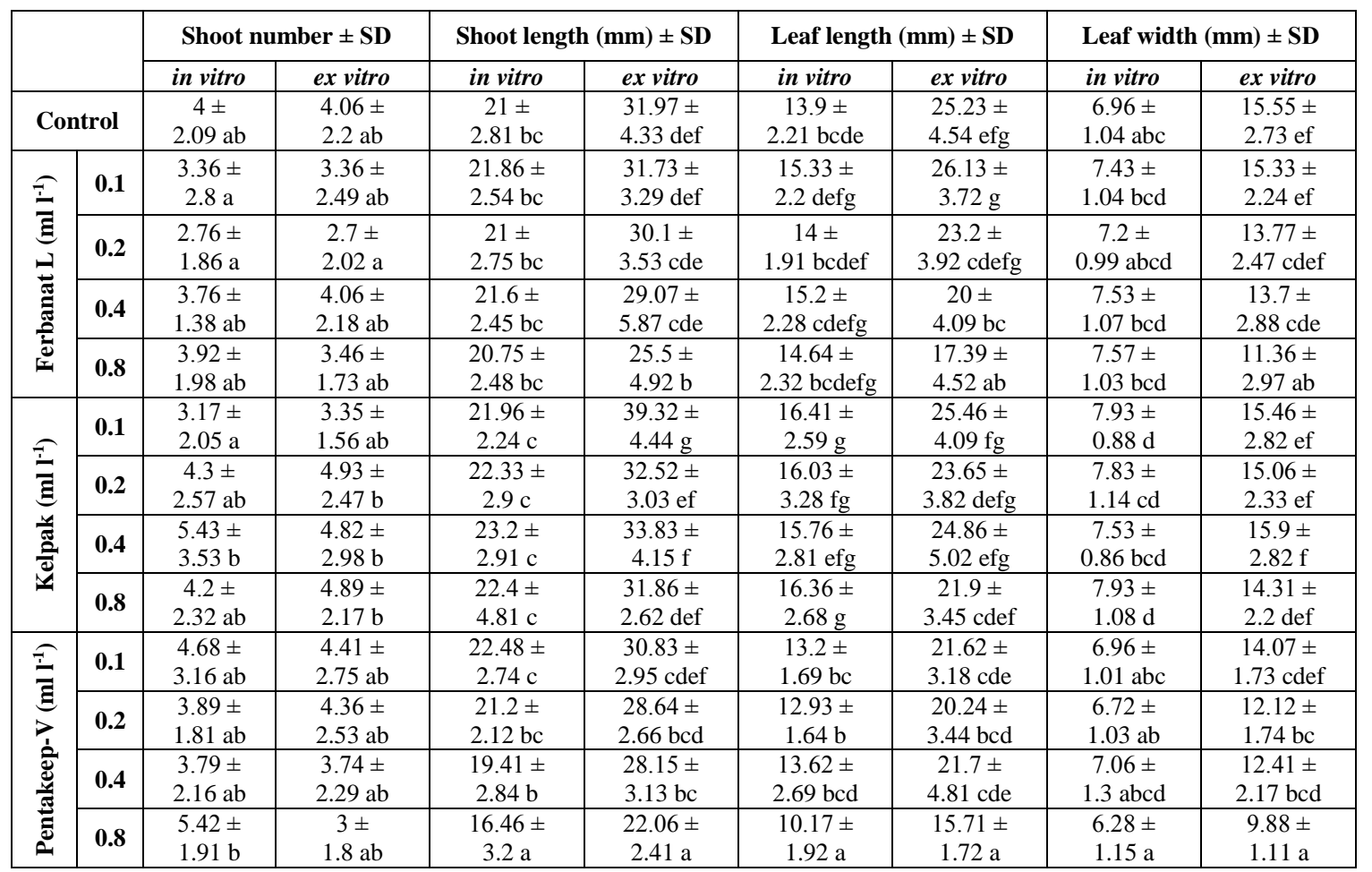

\section{Length and width of leaves}

Significantly the longest and widest Hosta 'Gold Drop' leaves were observed on in vitro plants grown on medium with 0.1 and $0.8 \mathrm{ml} \mathrm{l}^{-1}$ Kelpak (lengths: 16.41 and $16.36 \mathrm{~mm}$, widths: equally $7.93 \mathrm{~mm}$ ) comparing to the control. Similar tendency was experienced during in vitro propagation of Sorbus borbasii 'Herkulesfürdő' (Vidák, 2014). In our experiment, Pentakeep resulted the shortest and narrowest (in vitro and ex vitro) leaves especially when the highest dosage $\left(0.8 \mathrm{ml} \mathrm{l}^{-1}\right)$ was applied (Table 2). Different treatments effected different proportions of the shoot number, - sizes and leaf parameters: if $0.8 \mathrm{ml} \mathrm{l}^{-1}$ Pentakeep was used, there were negative correlation between the number and the length of shoots and leaves. On the other hand, Kelpak resulted more and longer shoots with larger leaves. Pentakeep, Ferbanat, Kelpak effected shorter and narrower in vitro Hosta 'Dew Drop' leaves as comparing to the control, but in the case of the latter 2 biostimulators' after-effect, larger leaves were found on acclimatized plants (Gere, 2017).

\section{Chlorophyll and carotenoid content}

In vitro, there was positive coherence between chlorophyll content and size (length, width) of leaves, so the highest values were achieved in the case of 0.1 and $0.8 \mathrm{ml} \mathrm{l}^{-1}$ Kelpak (5169.56 and $\left.5397.33 \mu \mathrm{g} \mathrm{g}^{-1}\right)$, and the lowest $\left(2988.33 \mu \mathrm{g} \mathrm{g}^{-1}\right)$ on medium with $0.8 \mathrm{ml} \mathrm{l}^{-1}$ Pentakeep. Similar tendency was obtained when carotenoid contents were examined. After acclimatization, the highest chlorophyll-values (5085.76 and $5012.58 \mu \mathrm{g} \mathrm{g}^{-1}$ ) were observed in groups previously in vitro propagated with the use of $0.1 \mathrm{ml} \mathrm{l}^{-1}$ Ferbanat and $0.4 \mathrm{ml} \mathrm{l}^{-1}$ Kelpak (and every dozes of Pentakeep after-effected the lowest levels, Figure 2). On the other hand, carotenoid contents changed differently, because significantly the highest averages (130.61-142.31 $\mu \mathrm{g} \mathrm{g}^{-1}$ ) were recorded in the case of the latter biostimulator with higher doses (Figure 3). In the study of Hosta 'Dew Drop', mainly Kelpak increased (and Pentakeep decreased) chlorophyll and carotenoid contents of in vitro and acclimatized plants (Gere, 2017), however, the highest concentration of Pentakeep resulted the highest leaf pigment values of in vitro Philodendron erubescens (Asztalos, 2014), Sorbus borbasii 'Herkulesfürdő' (Vidák, 2014) and acclimatized Phoenyx dactilifera (Awad, 2008) plants.

\section{Peroxidase enzyme activity}

Examining in vitro Hosta 'Gold Drop' plants, POD activity was the lowest $\left(0.019 \mathrm{U} \mathrm{mg}^{-1}\right)$ when $0.1 \mathrm{ml} \mathrm{l}^{-1}$ Kelpak was used, and Pentakeep resulted the highest values $\left(0.082\right.$ and $\left.0.073 \mathrm{U} \mathrm{mg}^{-1}\right)$, especially when higher doses were applied (Figure 4). In Gere's trial (2017), Pentakeep also effected the highest POD activity (0.12-0.15 $\left.\mathrm{U} \mathrm{mg}^{-1}\right)$ of in vitro Hosta 'Dew Drop', although the lowest in vitro values $\left(0.03-0.07 \mathrm{U} \mathrm{mg}^{-1}\right)$ were detected if Ferbanat was added to the medium. In most cases, there were no significant differences between ex vitro POD activities, nevertheless, every concentration of Kelpak, 0.1, $0.2 \mathrm{ml} \mathrm{l}^{-1}$ Ferbanat and 0.1, $0.4 \mathrm{ml} \mathrm{l}^{-1}$ Pentakeep decreased (as after-effect) values as compared with control. Different results were recorded if acclimatized Hosta 'Dew Drops' were examined, Kelpak and Ferbanat was not effective for this cultivar (Gere, 2017).

\section{Survival rate (acclimatization)}

Considering total groups, $92 \%$ of plants survived acclimatization. In according to the type of biostimulator, we observed the highest rates $(100 \%)$ in the case of Kelpak and Ferbanat in every concentration or $0.1 \mathrm{ml} \mathrm{l}^{-1}$ Pentakeep, and the lowest $(56 \%)$ when $0.8 \mathrm{ml} \mathrm{l}^{-1}$ of the latter biostimulator was used. We have to mention that $100 \%$ of the control plants also successfully survived acclimatization, thus, applied biostimulators had no concrete positive effect on the number of survived specimens. Supposedly, further ex vitro experiments with disadvantageously modified (for example drier, colder) conditions emphasize advantages of biostimulators. 


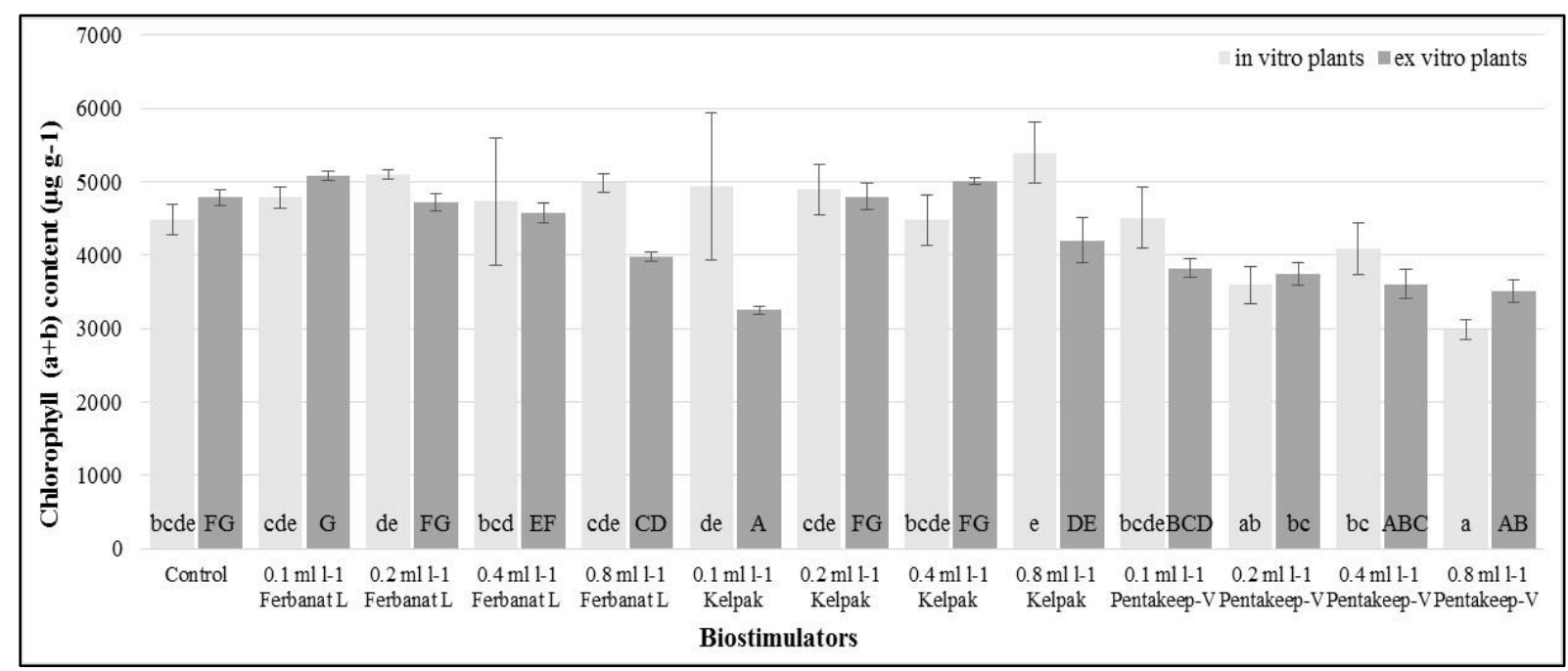

Figure 2. Chlorophyll $(\mathrm{a}+\mathrm{b})$ content of in vitro and ex vitro Hosta 'Gold Drop' plants. Values are mean \pm SD. Bars with different letter are significantly different by Tukey's and Games-Howell's comparison test at $\mathrm{p} \leq 0.05$

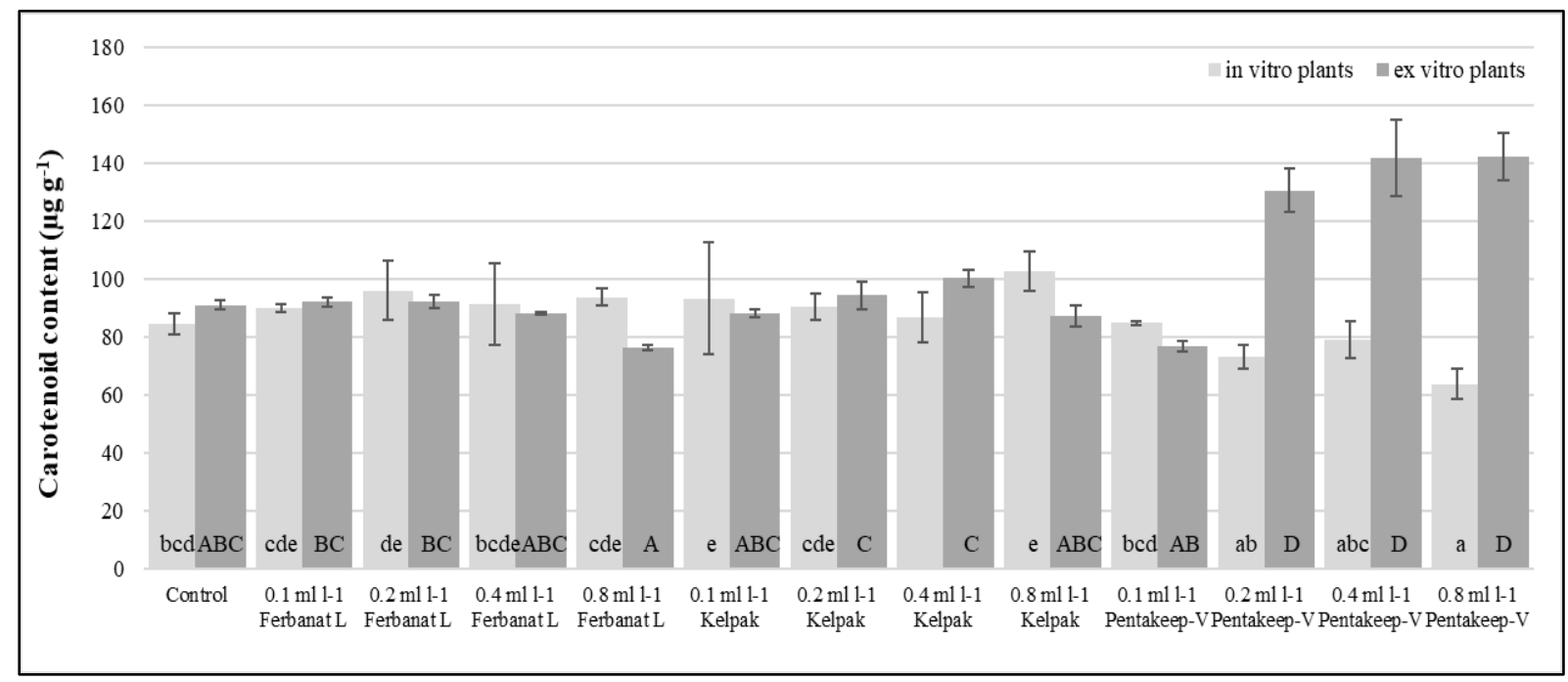

Figure 3. Carotenoid content of in vitro and ex vitro Hosta 'Gold Drop' plants. Values are mean \pm SD. Bars with different letter are significantly different by Tukey's and Games-Howell's comparison test at $\mathrm{p} \leq 0.05$

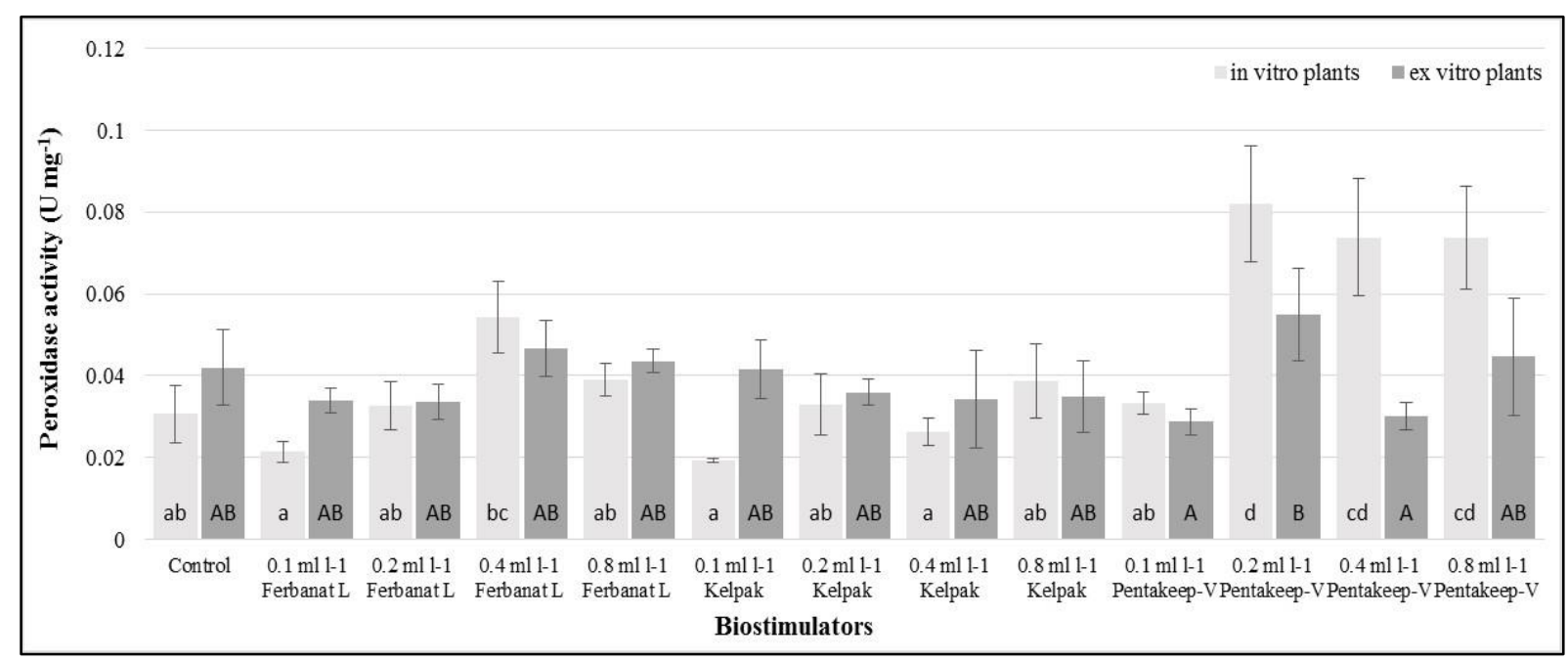

Figure 4. Peroxidase enzyme activity of in vitro and ex vitro Hosta 'Gold Drop' plants. Values are mean \pm SD. Bars with different letter are significantly different by Tukey's and Games-Howell's comparison test at $\mathrm{p} \leq 0.05$ 


\section{Conclusions}

Summarizing, Pentakeep-V was not optimal during micropropagation of Hosta 'Gold Drop' because of nonwanted or bad effects. For example, this product eventuated callus development on the basal part of the shoots: almost $40 \%$ of specimens developed globular-irregular, pale green formation when medium with $0.8 \mathrm{ml} \mathrm{l}^{-1}$ of Pentakeep was used. Root number, root length, leaf sizes (and chlorophyll, carotenoid content of leaves) also decreased in this case; therefore, almost half of these poorly grown plants did not survive acclimatization. We obtained the best results with applying Kelpak, especially in concentrations 0.2 or $0.4 \mathrm{ml} \mathrm{l}^{-1}$. The use of this product resulted higher in vitro fresh plant weight definitely because of more and longer shoot with larger leaves (not only in case of in vitro but acclimatized plants), and probably due to the stronger habit and higher concentration of chlorophyll pigments, $100 \%$ of the shoots were successfully acclimatized. Though all control plants also survived this procedure, the use of this agent is preferred (leastwise in case of this Hosta cultivar) because of the higher number and larger sizes of in and ex vitro shoots. In order to ascertain positive/negative effects of these environmental friendly products, further in vitro and acclimatisation trials with more Hosta taxa were suggested.

\section{References}

Adelberg, J., Kroggel M., Toler, J. (2000): Physical Environment in vitro Affects Laboratory and Nursery Growth of Micropropagated Hostas. HortTechnology 10(4): 754-757.

Adelberg, J. (2005): Efficiency in thin-film liquid system for Hosta micropropagation. Liquid Culture Systems for in vitro Plant Propagation 443-447. https://tigerprints.clemson.edu/cgi/ viewcontent.cgi? article $=1064 \&$ context $=$ ag_pubs

Arnon, D. I. (1949): Copper enzymes in isolated chloroplasts. Polyphenoloxidase in Beta vulgaris. Plant Physiol 24 (1): 1-15. http://www.plantphysiol.org/content/plantphysiol/24/1/1.full.pdf

Asztalos, J. (2014): Különféle növekedésszabályozó anyagok hatása a Philodendron erubescens mikroszaporításában. Budapest, Hungary: Corvinus University of Budapest, MSc thesis

Awad, M. A. (2008): Promotive effects of a 5-aminolevulinic acid-based fertilizer on growth of tissue culture-derived date palm plants (Phoenix dactylifera L.) during acclimatization. Sci Hortic 118 (1): 48-52.

Blinda, A., Abou-Mandour A., Azarkovich M., Brune A., Dietz K.J. (1996): Heavy metal-induced changes in peroxidase activity in leaves, roots and cell suspension cultures of Hordeum vulgare L. Plant Peroxidases, Biochemistry and Physiology. Geneva: University Geneva 380-385.

Bozek, M. Strzałkowska-Abramek, M. Denisow, B. (2015): Nectar and pollen production and insect visitation on ornamentals from the genus Hosta Tratt. (Asparagaceae). Journal of Apicultural Science 59 (29): 119-125. https://content.sciendo.com/view/journals/jas/59/2/articlep115.xml

Dąbrowski, Z. (2008): Field Crops. Preface. In: Dąbrowski Z (Ed.). Biostimulators in modern agriculture. Wieś Jutra, Warsaw, Poland p. 5-6.
Dobrzański, A., Anyszka, Z., Elkner, K. (2008): Reakcja marchwi na ekstrakty pochodzenia naturalnego $\mathrm{z}$ alg $\mathrm{z}$ rodzaju Sargassum - AlgaminoPlant i z leonardytu - HumiPlant. [Carrot response to natural extracts from Sargassum algae AlgaminoPlant and from leonardit - HumiPlant]. Journal of Research and Applications in Agricultural Engineering 53: 53-58.

Featonby-Smith, B. C., J. Van Staden (1984): Identification and seasonal variation of endogenous cytokinins in Ecklonia maxima (Osbeck) Papenf. Botanica Marina 17: 527-531.

Gere, A. J. (2017): Biostimulátorok hatásának vizsgálata Hosta 'Dew Drop' mikroszaporítása során. Budapest, Hungary: Corvinus University of Budapest, BSc thesis

Kisvarga, Sz., Kerezsi, R., Kohut, I., Tilly-Mándy, A. (2014): The effect of Ferbanat L nanofertilizer on the growing of Petunia x grandiflora 'Musica Blue'. Int J Hort Sci 20 (3-4): 107-109. https://ojs.lib.unideb.hu/IJHS/article/view/1144/1142

Kisvarga, Sz., Honfi, P., Tillyné Mándy, A. (2015): Effect of Pentakeep-V on Begonia $\times$ tuberhybrida 'Nonstop' line. Bulletin UASVM Horticulture. 72(1): 115-119. file://C:/Users/Ord4997/AppData/Local/Temp/10848-435581-PB.pdf

Knudson, L. (1946): A new nutrient solution for the germination of orchid seeds. Amer Orchid Soc Bull 15: 214 217.

Kosáry, J. (2008): [Biochemistry of storage. 2. Food biochemistry] A tárolás biokémiája 2. Élelmiszer-biokémia. Budapesti Corvinus Egyetem, Élelmiszertudományi Kar, Alkalmazott Kémia Tanszék, Internetes kiadás, p. 14-16. http://www.uni-corvinus.hu/fileadmin/user_upload/hu/ tanszekek/elelmiszertudomanyi/alkalmazottkemia/segedanyag_ ppt_pdf/TarbioElbio2008.DOC

Kovács, D., Magyar, L., Sütöriné Diószegi, M., Hrotkó, K. (2017): Treatments affecting the growth of Forsythia $x$ intermedia Zabel. 'Beatrix Farrand' container grown shrubs. Gradus 4 (2): 284-289. http://gradus.kefo.hu/archive/20172/2017_AGR_027_Kovacs.pdf

Kowalski, B., Jäger A. K., J. Van Staden (1999): The effect of a seaweed concentrate on the in vitro growth and acclimatization of potato plantlets. Potato Research 42: 131-139.

Köbli V., Honfi P., Túróczy M., Tilly-Mándy A. (2012): The influence of Kelpak ${ }^{\circledR}$ and Pentakeep- $\mathrm{V} \AA$ on the root formation of Pelargonium zonale 'Serena' cuttings. In: Perata P, Brown $\mathrm{P}$, Ponchet $\mathrm{M}$ editors. Abstract Book for Oral and Poster Presentations at: The 1st World Congress on the use of Biostimulators in Agriculture. 26-29. November 2012; Strasbourg, France: Strasbourg Congress Centre, p. 164.

Krzyminska, A. (2007): Influence of Pentakeep-V on yield and quality of tulip, allium, lilium bulbs and gladiolus corms. Conference papaer: Pentakeep International Scientific Workshop. Prague, Checz Republic, 1: 146-151. http://www.agroniwa.pl/files/07_praha_2007_dr_krzymindka.pdf

Liu, D. H., Zhao, S. W. (2012): The impacts of light levels on growth and ornamental characteristics of Hosta. Acta Hortic 977 (2013): 183-188.

Molnár, Z., Virág, E., Ördög, V. (2011): Natural substances in tissue culture media of higher plants. Acta Biologica Szegediensis 55 (1): 123-127. 
Magyar, L., Barancsi, Z., Dickmann, A., Hrotkó, K. (2008): Application of biostimulators in nursery. Bulletin UASVM Horticulture, 65 (1): 515.

Murashige, T., Skoog, F. (1962): A revised medium for rapid growth and bioassays with tobacco tissue cultures. Physiol Plant 15: 473-497. http://priede.bf.lu.lv/grozs/ AuguFiziologijas/Augu_audu_kulturas_MAG/literatura/ 03 Murashige\%20Scoog1962.pdf

Schmid, W. G. (1991): The genus Hosta. Portland, OR, USA: Timber Press

Shannon, L. M., Kay, E., Lew, J. Y. (1966): Peroxidase isozymes from horseradish roots. I. Isolation and physical properties. The Journal of Biological Chemistry. 241 (9): 2166-2172.

Szabó, V. (2015): Effect of biostimulators on rooting of Prunus mahaleb softwood cuttings. Budapest, Hungary: Corvinus University of Budapest, $\mathrm{PhD}$ thesis http://phd.lib.unicorvinus.hu/853/3/Szabo_Veronika_ten.pdf

Szabó, V., Hrotkó, K. (2009): Preliminary results of biostimulator treatments on Crataegus and Prunus stockplants. Bulletin UASVM Horticulture, 66 (1): 223-228.

Szabó, V., Sárvári, A., Hrotkó, K. (2011): Treatment of stockplants with biostimulators and their effects on cutting propagation of Prunus marianna 'GF 8-1', Acta Hortic. 923: 277-282. https://www.actahort.org/books/923/923_41.htm

Szafián, Zs. (2010): Biological and technological aspects of micropropagation of Hosta varieties. Budapest, Hungary: Corvinus University of Budapest, $\mathrm{PhD}$ thesis http://phd.lib.unicorvinus.hu/445/3/szafian_zsolt_ten.pdf

Takács, A., Köbli, V., Honfi, P., Tilly-Mándy, A. (2015): Biostimulátorok alkalmazása a vágottliliom-termesztésben. Kertgazdaság 47 (1): 40-47.

Tantos, Á. (2002): Study on the effects of naturally occurring growth regulators in the plant tissue culture. Budapest, Hungary: Szent István University, PhD thesis
Thuróczy, J. (2012): Myrmecophila tibicinis és Peristeria elata mikroszaporítása Ferbanat $\mathrm{L} \otimes$ tartalmú táptalajon. Budapest, Hungary: Corvinus University of Budapest, MSc thesis

Tilly-Mándy, A., Honfi, P., Marczika, A., Köbli, V., Palásti, Gy. (2010a): The Effect of Bioactive Agents on the Growth and Chlorophyll Content of Tillandsia usneoides L. Bulletin UASVM Horticulture. $67 \quad$ (1): 388-393. file://C:/Users/Ord4997/AppData/Local/Temp/5749-20662-1PB-1.pdf

Tilly-Mándy, A., Honfi, P., Stefanovits-Bányai, É., Mosonyi, I. D., Köbli, V., Hrotkó, K. (2010b): The effect of 5-aminolevulinic-acid (ALA) on the development of Saintpaulia ionantha. Int J Hortic Sci 16(5): 33-36. https://ojs.lib.unideb.hu/IJHS/article/view/931/929

Tilly-Mándy, A., Köbli, V., Honfi, P., Takács, A. (2012): Applying biostimulators in cut lily production. In: Kramarič M, Pogorolec A, Artiček MK, Jerala M, editors. 1. znanstvena konferenca $\mathrm{z}$ mednarodno udeležbo $\mathrm{s}$ področja kmetijstva, naravovarstva in hortikulture: Prenos inovacij, znanj in izkušenj v vsakdanjo rabo. 19-20 April 2012; Naklo, Slovenia: Biotechniški center Naklo, p. 17.

Vágújfalvi, D. (2007): [Porfirines] Porfirinek. In: Láng F.(ed./szerk.): [Plant Physiology, The Metabolism of Plants II.] Növényélettan, A növényi anyagcsere II.. Budapest. ELTE Eötvös Kiadó, p. 584-587.

Vidák, A. (2014): Biostimulátorok alkalmazásának lehetőségei Sorbus borbasii 'Herkulesfürdő' mikroszaporításában. Budapest, Hungary: Corvinus University of Budapest, MSc thesis

Yoshida, R., Ohta, E., Iwai, K., Tanaka, T., Okada, H. (2005): Effects of liquid fertilizer containing 5-aminolevulinic acid on thickening growth in tulip bulbs. In: Potter MA, Quill BE, editors. Proceedings of the 32nd Annual Meeting of the Plant Growth Regulation Society of America, 24-27 July; Newport Beach, California, USA, pp. 91-94. http://www.pgrsa.org/2005_Proceedings/papers/031.pdf 